\title{
DEMİRYOLU ISŞÇİLERINIIN ÇALIŞMA YAŞAMLARINDA KARŞILAŞTIKLARI GÜÇLÜKLER ÜZERİNE NİTEL BİR ÇALIŞMA
}

\author{
Yücel Uyanık $^{1}$ - $\underline{\text { Abdulkadir Yüksel }}^{2}$ \\ 1ORCID ID: orcid.org/0000-0002-6424-3672 \\ 20RCID ID: orcid.org/0000-0002-7038-1609
}

Öz

Türkiye'de demiryolları, taşımacılık alanında önemli bir konuma sahiptir. Osmanlı'dan kalan demiryolu ağı Cumhuriyet ile gelişim stratejilerinin temeline alınmış ve önemli bir milli servet haline gelmiștir. Türkiye Cumhuriyeti Devlet Demiryolları yıllardan beri bünyesinde yüzbinlerce ișçi ve memur çalıștıran Kamu Íktisadi Teșebbüsü niteliğinde bir kuruluștur. Bu araștırmanın amacı demiryolu ișçilerinin çalıșma yașamlarında karșllaștıkları birtakım güçlükleri belirlemek ve mevcut durumlarını betimlemektir. Araștırma nitel araștırma yöntemlerinden olgu bilim araștırması olarak tasarlanmıștır. Araștırmanın katılımcı grubu belirlenirken seçkisiz olmayan örnekleme yöntemlerinden amaçsal örneklem kullanılmıştır. Bu bağlamda araştırmanın örneklem grubunu 11 demiryolu işçisi oluşturmaktadır. Araştırmada veri toplama aracı olarak görüşme tekniği kullanılmıştır. Elde edilen veriler betimsel analize tabii tutularak demiryolu iş̧̧ilerinin çalışma yaşamlarındaki güçlükler vurgulanmıştır. Katılımcı ifadeleri doğrultusunda demiryolu iş̧̧ilerinin; ülkenin ekonomik şartları doğrultusunda ücret düzeylerinin yoksulluk sınırında kaldığı, sosyal harcamalarının ve tasarruflarının sınırlı olduğu, iş ortamlarında çeşitli iyileștirmelerin yapılması gerektiği ve iş sağlığı ve iş güvenliği konusunda gerekli önlemlerin yeterince alınmadığı sonucuna ulașılmıștır.

Anahtar Kelimeler: T.C. Devlet Demiryolları, demiryolu işçisi, sosyal politika.

Atıf için:

Uyanık, Y. ve Yüksel A. (2021). Demiryolu ișçilerinin çalıșma yașamlarında karșılaștıkları güçlükler üzerine nitel bir çalışma. HAK-ISS Uluslararası Emek ve Toplum Dergisi, 10(28), 391-408.

\footnotetext{
${ }^{1}$ Prof. Dr., Ankara Hacı Bayram Veli Üniversitesi, İktisadi ve İdari Bilimler Fakültesi, Çalışma Ekonomisi ve Endüstri İlişkileri Bölümü, Ankara, Türkiye

E-posta: y.uyanik@hbv.edu.tr

${ }^{2}$ Öğr. Gör. Dr., Sivas Cumhuriyet Üniversitesi Şarkışla Aşık Veysel Meslek Yüksekokulu, Sivas,, Türkiye E-posta: abdulkadiryuksel@cumhuriyet.edu.tr
} 


\title{
A QUALITATIVE STUDY ON THE DIFFICULTIES OF THE RAILWAY WORKERS FACED IN THE WORKING LIFE
}

\begin{abstract}
Railways in Turkey has an important position in the field of transportation. Takenover railway network from the Ottoman Empire has been taken as the foundation of development strategies and became an important national wealth. The Republic of Turkey State Railways is a Public Economic Enterprise that has been employing hundreds of thousands of workers and civil servants for years. The aim of this research is to identify some of the difficulties that railway workers face in their working life and to describe their current situation. The research was designed as a phenomenology research from qualitative research methods. Purposive sampling, one of the non-random sampling methods, was used while determining the participant group of the study. In this context, the sample group of the research consists of 11 railway workers. Interview technique was used as a data collection tool. Obtained data were analyzed descriptively and the difficulties in working life of railway workers were emphasized. As a result of the analyzes and in accordance with the participant worker expressions; In line with the economic conditions of the country, it has been concluded that wage levels remain at the poverty line, social expenditures and savings are limited, various improvements in the work environment should be made and necessary precautions are not taken in terms of occupational health and safety.
\end{abstract}

Keywords: The Republic of Turkey State Railways, railway worker, social policy 


\section{Giriş}

Dünyada Endüstri Devrimi ile birlikte, ulaşımın ve taşımacılığın önemi daha çok artmaya başlamıştır. Üretimin artması, bölgeler ve ülkeler arası ticaret hacminin gelişmesi gibi etkenler taşımacılık sektörünün gelişmesini tetikleyen unsurlardan olmuştur. Ulaştırma ve taşımacıllk sadece Endüstri Devrimi'nin başladığı Avrupa coğrafyasında değil tüm dünyada önemi hızla artan sektör haline gelmiştir. Demiryolları da bu bağlamda taşımacılık ve ulaştırma hizmetlerinde önemli bir yer almaktadır. Demiryollarının sistem ve ağının kurulması maliyetli fakat yapım aşamasının sonrasında taşıma kapasitesinin yüksek olması ve taşıma maliyetlerinin düşük olması demiryollarını tercih edilen taşıma aracı yapmaktadır.

Demiryolu hizmetleri ülkemizde Türkiye Cumhuriyeti Devlet Demiryolları (TCDD) tarafından yürütülmektedir. TCDD, demiryolu ağının yapımı, geliştirilmesi, bakım-onarım ve işletilmesi gibi tüm işlemlerini yürütmekle görevlidir. Bu bağlamda TCDD bünyesinde 2019 verilerine göre toplam 27.260 personel görev yapmakta ve bu personelin 11.513'u daimî işçi statüsünde çalışmaktadır (TCDD İstatistik Yıllığı, 2020, s.23). Liman ve Feribot Yönetimi Dairesi ve Teşkilleri Hak İşçi Sendikaları Konfederasyonu'na bağlı Liman-İş Sendikası yetkisinde yer almaktadır. Liman ve Feribot Yönetimi Dairesi ve Teşkillerinde 1242 personel görev yapmakta ve bu personelin 669'u daimi işçi statüsündedir (TCDD İstatistik Ylllığı, 2020, s.23). Bu bağlamda TCDD bünyesindeki diğer işçiler Türkiye İşçi Sendikaları Konfederasyonuna (Türkİş) bağlı Türkiye Demiryolu İşçileri Sendikasına (Demiryol-İş̧) üye durumdadırlar. Taşımacılık iş kolunda faaliyet gösteren Demiryol-İş toplu sözleşme masasında yetkili sendika konumundadır. Son olarak 15.10.2019 tarihinde imzalanan 28. dönem toplu iş sözleşmesi aktif olarak devam etmektedir.

Demiryolu işçilerinin çalışma şartları ve koşulları, özlük hakları gibi tüm çalışma yaşamlarına ait kurallar 28. dönem toplu iş sözleşmesinde ifade edilmektedir. Alan yazın incelendiğinde ise demiryolu işçilerinin çalışma koşullarından kaynaklanan sağlık sorunları (Altundaş, Arslan, Akıngöl, Varol, Turan ve Kalaça, 2010, s.36) ve iş kazaları ile iş güvenliği gibi konulara odaklanan çalışmalar olduğu görülmüştür (Budakoğlu, Bakar, Atlı ve Akgün, 2015, s.27; Koçak, 2014, s.3). Ancak demiryolu işçilerinin iş sağllğı ve güvenliği konularının dıșında da bazı güçlüklerle karșılașabilecekleri öngörülmektedir.

Osmanlı Döneminden beri varlığını sürdüren bir meslek grubu olarak demiryolu işçilerinin yaşadıkları fakat derinlemesine bilgi sahibi olunmayan güçlüklerin ortaya çıartılması ve bu güçlüklerin bütüncül bir bakış açısı ile betimlenmesinin gerekliliği öne çıkmaktadır. Bu sebeple, bu araştırmanın alan yazına katkıda bulunacağı düşünülmektedir. Bu bağlamda araştırmanın amacı Türkiye'de taşımacılık iş kolunda önemli bir yere sahip olan demiryolu işçilerinin çalışma hayatlarında karşılaştıkları bir takım güçlüklerin belirlenmesidir. Bu temel amaç doğrultusunda aşağıdaki sorulara yanıt aranmıştır. 
- Demiryolu işçilerinin gelir ve yaşam koşullarına ilişkin yaşadıkları güçlükler nelerdir?

- Demiryolu işçilerinin iş ve iş ortamlarına ilişkin yaşadıkları güçlükler nelerdir?

- Demiryolu işçilerinin iş sağlığı ve iş güvenliği konusunda karşılaştıkları güçlükler nelerdir?

\section{TCDD'ye Genel Bakış}

Demiryolu taşımacılığı tüm dünyada vazgeçilmez bir ulaşım yolu olmasının yanı sıra ülkeler için sanayi ve ekonomik gücün bir göstergesi olarak da gelişim göstermiştir (Demiryol-İş, 1996, s. 49). 19. yy'da yaşanan endüstri devrimiyle birlikte buharlı makinaların kullanımı sonucunda demiryolları ulaşım aracı olarak ortaya çıkmıştır (Kahya, 1988, s.209). Endüstri devriminin getirdiği rekabet ortamında olan Avrupa devletlerinde demiryolları hızlı bir şekilde yaygınlaşmış ve gelişim göstermiştir. Türkiye tarihi açısından demiryollarının gelişimi incelendiğinde ise ilk demiryolu hattının Osmanlı İmparatorluğu döneminde, Hindistan yolunu kontrol etmek isteyen İngilizler tarafından 1854 yılında yapıldığı görülmektedir (Akbulut, 2012, s. 226). TCDD tarihi açısından ise ilk demiryolu hattı 1856 yllında yapılan $130 \mathrm{~km}$ uzunluğundaki İzmir- Aydın Demiryolu hattıdır (TCDD, 2017, s.10). Devam eden süreçte İzmir- Kasaba, Rumeli, Hicaz ve Anadolu- Bağdat Demiryolu hatlarının inşa edildiği görülmektedir (Akalan, 2010, s.13-29).

Batılılaşma düşüncesinin hâkim olduğu dönemde Osmanlı topraklarında yapılan demiryolu hatlarının yapımını Avrupa Devletleri'nin üstlendiği görülmektedir. Osmanlı İmparatorluğu üzerinde bulunan demiryolu hatlarını genel olarak iki grupta toplamak mümkündür. Bunlardan ilki Balkan Demiryolları (İstanbul- Sırbistan- Londra hattı ve Selanik- Makedonya- Bosna hattı); ikincisi ise Anadolu Demiryollarıdır (Kahya, 1988, s.211-212). Bu dönemde Osmanlı İmparatorluğu Almanya, İngiltere ve Fransa'ya çok geniş imtiyazlar tanımıștır ve demiryollarının bahsi geçen Avrupa ülkelerine yaptırılması için maliyetinin çok üstünde bedeller ödemiştir (Akalan, 2010, s.40-41).

Osmanlı Döneminde mevcut olan $8.619 \mathrm{~km}$ demiryolu hattının sadece 4.136 km'lik kısmı milli sınırlarımız içindedir ve hatların 2.404 km'si yabancı şirketler tarafından işletilmektedir (TCDD, 2017, s.10). Cumhuriyet'in ilanı ile birlikte 24 Mayıs 1924 tarihinde 506 Sayılı Kanun gereğince demiryollarının yabancı sermayeden satın alınarak millileștirilmesine karar verilmiștir (Altınok, 2004, s.77). Cumhuriyet öncesinde yapılan bu hatların millileştirilmesi 1928- 1948 yılları arasında tamamlanmıștır (TCDD, 2017, s.11). 1953 tarihine gelindiğinde ise 6186 sayılı Kanunla "Türkiye Cumhuriyeti Devlet Demir Yolları İşletmesi" adını alarak İktisadi Devlet Teşekkülü sıfatı almıș olup 1984 tarihinde 233 sayılı KHK ile Kamu İktisadi Kuruluşuna dönüştü- 
rülmüş̧ür (TCDD, 2017, s.11). Cumhuriyet'in ilk yıllarında tüm alanlarda görüldügü gibi demiryolu işletmeleri açısından da büyük gelişmeler yaşanmıştır. 1950'li yıllarda yaşanan ulaşım sektöründeki değişim hareketine kadar Türkiye Cumhuriyeti'nde bulunan demiryolu hat uzunluğu 10.429 km'ye ulaşmıștır ayrıca mevcut demiryolu hatlarının bakım ve onarımı işleri de yapılmıştır (Akalan, 2010, s.110; Altınok, 2004, s.77). 1950'li yıllarda karayolu ulaşımına ağırlık verilmesi demiryolu ulaşımını olumsuz yönde etkilemiştir. Cumhuriyet sonrası demiryolu gelişimi özet olarak siyasi, askeri ve iktisadi kalkınma için ülkeyi baştanbaşa demiryolu ile donatmak ve hatların millileştirilerek ulusun menfaatlerine hizmet edecek şekilde tanzim etmek olarak ifade edilmektedir (Akalan, 2010, s.202).

Türkiye'ye yabancı sermayenin getirdiği demiryolu personelinin eğitimi ile ilgili bilinen ilk çalışma 1915 yılında kurulan İzmir Şimendifer okuludur (Kent ve Demiryolu, 2014). 1932 yılına gelindiğinde ise Eskişehir Cer Atölyesi bünyesinde atölyede çalışanların çocuklarının meslek edinmesini sağlamak amacıyla çırak okulu açılmıştır (Şenol, 1994, s.18). Bu okuldan mezun olan öğrenciler fabrikada öncelikle işçi muavini akabinde ise işçi olarak çalışmıştır (Şenol, 1994, s.18).

1942 yllında ise TCDD’nin ihtiyaç duyduğu nitelikli personelin yetiştirilmesi amacıyla Ankara'da Demiryolu Meslek Okulu kurulmuş ve ülke çapında yaygınlaştırılmıştır (Kent ve Demiryolu, 2014). Bu eğitim kurumları 1998 yılında TCDD Yönetim Kurulu kararıyla kapatılmıştır (Kent ve Demiryolu, 2014). Çırak okulları ve Demiryolu Meslek Okulları pratik ile uygulamayı birleștiren eğitim kurumlarıdır. Bu eğitim kurumları TCDD'nin uzun yıllar boyunca nitelikli personel ihtiyacını karşılamıștır. Ancak günümüzde bu uygulamalara son verilmiştir ve TCDD'nin sadece mevcut personelinin eğitim ihtiyaçlarını karşılamak üzere çeşitli "meslek içi eğitim" faaliyetlerini yürüttüğü eğitim merkezleri bulunmaktadır.

\section{TCDD'nin Görevleri}

233 Sayılı Kamu İktisadi Teşebbüsleri Hakkında Kanun Hükmünde Kararname esaslarına tabi olarak faaliyette bulunmak üzere "Türkiye Cumhuriyeti Devlet Demiryolları İşletmesi Genel Müdürlügü adı altında teşkil olunan işletmenin amaç ve görevleri, ana başlıklar itibariyle aşağıdaki şekilde sıralanabilir (TCDD İstatistik yıllı̆̆ı, 2009, s.19):

- Devletçe kendisine verilen demiryolları, liman, rıhtım ve iskeleleri; işletmek, genişletmek ve yenilemek,

- Kanun, tüzük, yönetmelikler ile kalkınma ve yıllık programlar çerçevesinde bağlı ortaklarını ve iștiraklerini yönlendirmek ve bunlar arasinda koordinasyonu sağlamak,

- Gerektiğinde tamamlayıcı işler olarak feribot dâhil her türlü denizyolu ve karayolu taşıma işlerini yapmak, 
- Çeken ve çekilen araç ve gereçler ile benzerlerini yapmak ve yaptırmak, görevlerinin gerektirdiği ambar, antrepo, depo ve benzeri tesisler ile yolcu gereksinimleri için gerekli tesisleri kurup işletmek,

- Yurt içinde ve dışında yapılmakta veya yapılacak olan demiryolu inşaatlarını yalnız başına veya ortaklık halinde üstlenmek,

- Faaliyet konuları ile ilgili olarak Bakanlar Kurulu tarafından verilen görevleri yapmakla yükümlü bulunmaktır.

\section{Organizasyon Yapısı}

TCDD, Ulaştırma ve Altyapı Bakanlığı'na bağlı olarak faaliyet göstermektedir. TCDD İstatistik Yıllığından faydalanılarak yapılan derlemeye göre TCDD’nin organizasyon yapısı aşağıdaki şekliyle özetlenebilir.

Başkanı Genel Müdür olmak üzere, başkan ve beş üyeden meydana gelen Yönetim Kurulu ile Genel Müdür ve beș Genel Müdür Yardımcısından kurulu yürütme organı TCDD’nin yüksek kademedeki sevk ve idare teşkilatını oluşturmaktadır.

Merkezi Yönetim 16 İhtisas Daire Başkanlığı ile Teftiş Kurulu Başkanlığı, Hukuk Müşavirliği ve Basın Yayın Halkla İlişkiler Müşavirliği, İç Denetim Dairesi Başkanlığı birimleri ile Yönetim Kurulu Müdürlüğü, Demiryolu Araştırma ve Teknoloji Merkezi (DATEM) İşletme Müdürlüğünden oluşmaktadır (TCDD İstatistik yıllığı, 2017, s.2). Demiryolu altyapı işletmeciliği ile ilgili hizmetler 8 Bölge Müdürlügünce yürütülmektedir. Ayrıca Haydarpaşa ve İzmir Limanında verilen hizmetlerin sorumluluğu Genel Müdürlüğe aittir. Sivas ve Afyonkarahisar'da kurulu Beton Travers Fabrikaları, Ankara'da Ray Kaynak ve Yol Makinaları Onarım Fabrikası ve Çankırı'da kurulu Çankırı Makas Fabrikası bulunmaktadır. Diğer yandan TCDD'nin 3'ü demiryolu endüstrisi, 1'i taşımacılık alanında faaliyet gösteren dört bağlı ortaklığı bulunmaktadır. Bağlı ortaklıklar (TCDD İstatistik yıllı̆̆ı, 2009, s.12):

- TCDD TAŞIMACILIK A.Ş. (Ankara), Demiryolu Tren İşletmecisi olarak yük taşımacılığı, yolcu taşımacılığı, lojistik hizmetleri, feribot işletmeciliği ile çeken ve çekilen araçların temin ve bakım-onarım faaliyetleri yapılmaktadır.

- TÜLOMSAŞ, (Türkiye Lokomotif ve Motor Sanayi Anomim Şirketi, Eskişehir) Lokomotif ve yük vagonu üretimi ve onarımı, her çeşit dizel elektrik motorları ve cer motorları üretimi yapılmaktadır.

- TÜVASAŞ, (Türkiye Vagon Sanayi Anomim Şirketi Adapazarı) Dizelli tren seti, elektrikli dizi ve yolcu vagon üretimi ve onarımı yapılmaktadir.

- TÜDEMSAŞ, (Türkiye Demiryolu Makinaları Sanayi Anomim Şirketi, Sivas) Yük vagonları üretimi ve onarımı yapılmaktadır.

- Ayrıca TCDD’nin; İzmir'de İzmir Banliyö Taşımacıllğı Sistemi Ticaret AŞ (IZBAN), Ankara'da Raylı Sistemler Mühendislik ve Müşavirlik AŞ 
(RAYSIMAŞ), Adapazarı'nda Demiryolu Araçları Sanayi ve Ticaret AȘ (Hyundai EUROTEM AŞ), Çankırı'da Voestalpine Kardemir Demiryolu Sistemleri San. ve Tic. AŞ (VADEMSAŞ) ve Sivas'ta Sivas Travers İmalat Sanayi ve Ticaret AŞ (SİTAŞ) olmak üzere beş iştiraki bulunmaktadır (TCDD İstatistik yıllığı, 2009, s.12).

Aşağıdaki Tablo 1'de TCDD bünyesinde istihdam edilen personelin 20002019 yılları arasında çalışma statülerine göre dağılımı ve sayıları sunulmaktadir.

Tablo 1. 2000-2019 Yilları TCDD Personel Sayıları

\begin{tabular}{llllll}
\hline Yillar & Memur & $\begin{array}{l}\text { Sözleşmeli } \\
\text { Personel }\end{array}$ & Daimi İşçi & $\begin{array}{l}\text { Geçici İşçi } \\
\text { (Ortalama) }\end{array}$ & Toplam \\
\hline $\mathbf{2 0 0 0}$ & 1453 & 22524 & 21277 & 1958 & 47212 \\
$\mathbf{2 0 0 1}$ & 1442 & 22088 & 19998 & 1647 & 45175 \\
$\mathbf{2 0 0 2}$ & 1395 & 21291 & 18307 & 985 & 41978 \\
$\mathbf{2 0 0 3}$ & 1308 & 20068 & 16391 & 1256 & 39023 \\
$\mathbf{2 0 0 4}$ & 1204 & 18433 & 15933 & 3140 & 38710 \\
$\mathbf{2 0 0 5}$ & 1166 & 17334 & 15058 & 3296 & 33558 \\
$\mathbf{2 0 0 6}$ & 1160 & 16550 & 14247 & 3499 & 31957 \\
$\mathbf{2 0 0 7}$ & 1165 & 17433 & 17067 & 445 & 35665 \\
$\mathbf{2 0 0 8}$ & 1115 & 16902 & 16419 & 705 & 34436 \\
$\mathbf{2 0 0 9}$ & 1087 & 16343 & 15293 & 1275 & 32723 \\
$\mathbf{2 0 1 0}$ & 1042 & 16010 & 14162 & 1428 & 32642 \\
$\mathbf{2 0 1 1}$ & 1178 & 15781 & 14266 & 1577 & 32802 \\
$\mathbf{2 0 1 2}$ & 1196 & 15928 & 13824 & 909 & 31857 \\
$\mathbf{2 0 1 3}$ & 1075 & 14185 & 13778 & 863 & 29901 \\
$\mathbf{2 0 1 4}$ & 1057 & 14499 & 13408 & 865 & 29829 \\
$\mathbf{2 0 1 5}$ & 1030 & 14389 & 13405 & 766 & 29590 \\
$\mathbf{2 0 1 6}$ & 1002 & 14075 & 12425 & 644 & 28146 \\
$\mathbf{2 0 1 7}$ & 960 & 13665 & 11849 & 654 & 27128 \\
$\mathbf{2 0 1 8}$ & 987 & 13850 & 11718 & 985 & 27540 \\
$\mathbf{2 0 1 9}$ & 1039 & 13615 & 11513 & 1093 & 27260 \\
\hline
\end{tabular}

Kaynak: TCDD Ístatistik Ylllı̆ı̆ 2000-2004, 2002-2006, 2006-2010, 2010-2014, 2013-2017,2015-2020

Tablo 1 incelendiğinde TCDD bünyesinde memur, sözleşmeli personel, daimi işçi ve geçici işçi statüsünde 4 farklı çalışan tipinin istihdam edildiği görülmektedir. Bunlardan sözleşmeli personel memur yükümlülüğünde çalışmaktadır. Geçici işçiler ise işin gereği ve durumuna göre mevsimlik olarak talep edilmektedir ve Toplu İş Sözleşmesinden faydalanabilmektedirler.

Yıllara göre incelendiğinde personel sayılarında genel olarak bir düşüş söz konusudur. Demiryolu hat uzunluğunun artmasına rağmen personel sayısının azalmasının farklı sebepleri bulunmaktadır. Bu sebeplerden bazıları şu şekildedir; kalifiye olmayan işlerde hizmet alımına gidilmesi, emek faktörü yerine teknoloji kullanılması ve maliyetlerin kısılması adına işçilerin iş yükünün artırılarak daha az personel ile aynı verimin elde edilmeye çalışmasi. 


\section{Yöntem}

Demiryolu işçilerinin çalışma yaşamlarında karşılaştıkları güçlükleri belirlemek amacıyla yapılan bu araștırma; nitel araștırma yöntemlerinden olgu bilim desenine göre tasarlanmıştır. Nitel araştırma yöntemi; araştırma problemini anlama ve yorumlama amacıyla ele alınan, varsayım ve kuram ile sonuçlanabilen, sayısallaştırmanın pek mümkün olmadığı ya da az olduğu bir araştırma yöntemidir (Glesne, 2012, s.12). Bu bağlamda nitel araştırmalar doğal ortamda meydana gelen olay, olgu ve davranışlar üzerine odaklanan tümevarımcı araştırma yöntemleridir (Büyüköztürk, vd. 2014, s.241). Olgu bilim deseni üzerine tasarlanan araştırmalarda farkında olunan ancak ayrıntılı ve derinlemesine bir bilgiye sahip olunmayan olgular üzerine çalışılır (Yıldırım ve Şimşek, 2013, s.81). Olgu bilim araştırmaları kesin ve genellenebilir sonuçlar ortaya koymayabilir fakat olguyu daha iyi anlamaya yardımcı olacak örnekler, açıklamalar ve yaşantılar ortaya koyabilmektedir (Yıldırım ve Şimşek, 2013, s.81). Olgu bilim araştırmaları bize tam anlamıla yabancı olmayan aynı zamanda da tam olarak anlamını kavrayamadığımız olguları araştırmayı amaçlayan çalışmalar için uygun bir araştırma zemini oluşturur (Ylldırım ve Şimşek, 2013, s.78).

\section{Veri Toplama Aracı}

$\mathrm{Bu}$ araştırmada veri toplamak amacıyla olgu bilim araştırmalarında sıklıkla kullanılan görüşme tekniği kullanılmıștır. Görüşme, katılımcıların konu ile ilgili fikirlerini almak ve bakış açılarını belirlemek amacıyla kullanılan bir veri toplama tekniğidir (Patton, 2014, s.341). Bu araştırmada veri toplamak amacıyla araştırmacı tarafından ilgili alan yazın taranarak görüşme formu hazırlanmıştır. Hazırlanan görüşme formunun kapsam geçerliliğini sağlamak adına bir sosyal politika ve bir ölçme değerlendirme alan uzmanına sunularak uzman görüşü alınmıștır. Uzmanlardan alınan dönütler doğrultusunda ilgili düzenlemeler yapılarak katılımcı grubuna benzer özellikteki bir birey üzerinde pilot çalışma yapılmıştır. Pilot çalışma sonrasında görüşme formuna son hali verilmiştir. Görüşme formunun birinci bölümünde demografik bilgilere ilişkin sorular yer almaktadır. İkinci bölümde ise konu temalarına göre; gelir ve yaşam koşullarına ilişkin, çalışma koşulları ve çalışma ortamlarına ilişkin ve iş sağlığı ve iş güvenliğine ilişkin soruları bulunmaktadır. Görüşme formu 12 madde ve sonda sorularından oluşmaktadır.

\section{Katılımcılar}

Nitel araştırmalarda örneklem büyüklüğü belirlenirken nicel araştırmalardan farklı olarak kesin ve kurallı bir yaklaşım bulunmamaktadır ve kullanılan 
araştırma deseni ve veri toplama tekniğine göre farklı sayıda katılımcı ile çalışılabilir (Nastasi, 2015, s.4). Bu araștırmanın katılımcı grubu belirlenirken seçkisiz olmayan örnekleme yöntemlerinden amaçsal örneklem kullanılmıştır. Nitel araştırmalarda amaçsal örneklem belirli bir konunun derinlemesine ve ayrıntılarıyla birlikte incelenmesine olanak tanır (Patton, 2014, s.46). Nitel araştırmalar nicel araştırmalara göre genellenebilir sonuçlara odaklanmamaktadır. Bu bağlamda örneklem büyüklüğü belirlenirken belirli standartlar bulunmamaktadır. Alan yazında "doyma noktası" olarak ifade edilen, araştırmacının topladığı verilerde tekrara düştüğü noktada veri toplama işlemi sonlandırılmaktadır. Olgu bilim araştırmalarında örneklem grubu belirlenirken " $6 \leq$ katılımcı sayısı $\leq 10$ " şeklinde olması tercih edilmektedir (Creswell, 1998; Morse, 1994; akt. Collins, Onwuegbuzie ve Jiao, 2006, s.86). Bu araștırmanın katılımcı grubunu Türkiye Cumhuriyeti Devlet Demir Yolları Sivas Lokomotif Bakım Atölyesi Müdürlüğü bünyesinde çalışan 11 işçi oluşturmaktadır. Araştırmada veri toplama sürecinde doyma noktası kuralına dikkat edilmiştir ve 11. işçi ile yapılan görüşmede tekrara düşüldüğüne karar verilerek veri toplama süreci sonlandırılmıştır. Örneklem grubuna Lokomotif Bakım Atölyesi işçilerinin seçilmesindeki amaç ilgili departmandaki iş yükünün daha yoğun olmasıdır. Araştırmanın bu bölümünden sonra etik değer-

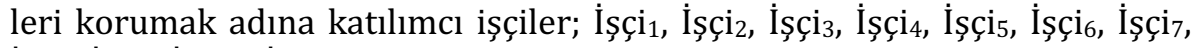
İşçi ${ }_{8}$, İşçi, İşçi $i_{10}$, Isş̧i $i_{11}$ şeklinde ifade edilmiştir. Araştırmanın katılımcılarına ait demografik bilgiler Tablo 2'de sunulmaktadır.

Tablo 2. Katılımcıların Demografik Bilgileri

\begin{tabular}{|c|c|c|c|c|c|c|}
\hline $\begin{array}{l}\text { Değişken/ } \\
\text { Katılımcı }\end{array}$ & Yaş & Cinsiyet & $\begin{array}{l}\text { Medeni Du- } \\
\text { rum }\end{array}$ & $\begin{array}{l}\text { Çocuk } \\
\text { Sayısı }\end{array}$ & $\begin{array}{l}\text { Hane } \\
\text { Nüfus }\end{array}$ & $\begin{array}{l}\text { Çalışma } \\
\text { Süresi }\end{array}$ \\
\hline İşçi ${ }_{1}$ & 30 & Erkek & Evli & 1 & 3 & $7 \mathrm{yll}$ \\
\hline İşçi & 54 & Erkek & Evli & 3 & 5 & $19 \mathrm{yll}$ \\
\hline İşçi & 55 & Erkek & Evli & 4 & 4 & $39 \mathrm{yll}$ \\
\hline İşçi & 51 & Erkek & Evli & 2 & 2 & $37 \mathrm{yll}$ \\
\hline İşçi & 44 & Erkek & Evli & 1 & 3 & $30 \mathrm{yll}$ \\
\hline İşçí & 32 & Erkek & Evli & 3 & 5 & $10 \mathrm{yll}$ \\
\hline İşçi & 46 & Erkek & Evli & 2 & 5 & $23 \mathrm{yll}$ \\
\hline İşçis & 31 & Erkek & Bekâr & - & 1 & 8 yll \\
\hline İşçì & 52 & Erkek & Evli & 2 & 5 & $25 \mathrm{yll}$ \\
\hline İşçi & 38 & Erkek & Evli & 3 & 5 & $14 \mathrm{yll}$ \\
\hline İsç̣i $i_{11}$ & 29 & Erkek & Bekâr & - & 4 & $6 \mathrm{yll}$ \\
\hline
\end{tabular}

Tablo 2'ye göre katılımcı işçilerin yaş aralığı 29 ile 55 arasında değişmektedir. Katılımcı işçilerin tamamı erkektir. Katılımcılardan 2 işçi bekâr 9 işçi evlidir. Evli olan katılımcı işçilerin hepsi çocuk sahibi olup çocuk sayıları 1 ile 4 arasında değişmektedir. Katılımcıların çalışma sürelerine bakıldığında 6 ile 39 yll arasında değiştiği görülmektedir. Katılımcı işçilerden; işçi $i_{2}$ işçi $i_{3}$, isçi ${ }_{4}$, işçi ${ }_{5}$ ve işçiو mesleki eğitimlerini TCDD çıraklık okulunda 2 yıl süre ile almışlardır ve bu süre çalışma sürelerine dâhildir. 


\section{Veri Toplama Süreci}

Bu araştırmanın verileri 2019 yılı Eylül- Kasım ayları arasında Sivas İlli Merkez İlçesinde Devlet Demir Yolları Sivas Lokomotif Bakım Atölyesi Müdürlügünde görev yapmakta olan 11 işçiden toplanmıştır. Veri toplama işlemi 2020 öncesi yapıldığı için Etik Kurul Onayı bulunmamaktadır. Araştırmanın veri toplama sürecinde öncelikle kurum yetkilileri ile görüşülerek araştırmanın amacı ve kapsamı ile ilgili bilgi verilmiş ve iş̧̧ilere araştırmaya katılmalarını davet etmek üzere duyuru yapılmıştır. Araştırmaya katılma konusunda gönüllü olan 11 işçi ile çalışma saatleri dışında olmak üzere görüşmenin yapılacağı gün ve saat için randevu alınmıştır. Görüşme günü katılımcı ve araştırmacı bire bir olacak şekilde yüz yüze görüşmeler gerçekleştirilmiştir. Öncelikle katılımcı işçilere araştırmanın amacı ve kapsamı hakkında bilgi verilerek bilgilendirilmiş onam formunu okumaları ve katılıma gönüllükleri hususunda yazılı izinleri alınmıştır. Görüşmeler sırasında veri kaybını önlemek amacıyla ses kayıt cihazı katılımcının onayı doğrultusunda kullanılmıștır. Araştırma sürecinde öncelikle katılımcıların demografik bilgileri alınmıştır. Sonrasında çalışma yaşamlarında karşılaştıkları güçlükleri belirlemek amaclyla; gelir ve yaşam koşulları, iş ve iş ortamları, iş sağlığı ve iş güvenliğine yönelik sorular yöneltilmiştir. Araştırmacı görüşme sırasında katılımcıya herhangi bir müdahalede bulunmamış ve süre kısıtlaması yapmamıștır. Görüşmeler ortalama 20- 25 dakika sürmüştür.

\section{Verilerin Analizi}

$\mathrm{Bu}$ araştırmadan elde edilen verilerin analizinde nitel araştırmalarda sıklıkla tercih edilen betimsel analiz tekniği kullanılmıștır. Betimsel analizde veriler önceden belirlenen temalar çerçevesinde özetlenerek yorumlanır (Yıldırım ve Şimsek, 2013, s.256). Betimsel analizde araştırma bulguları düzenlenmiş ve yorumlanmış biçimde sunulur ve anlatımı güçlendirmek amacıyla katılımcıların direkt ifadelerine yer verilir (Yıldırım ve Şimşek, 2013, s.256). Bu bağlamda demiryolu işçilerinin çalışma hayatlarında karşılaştıkları güçlüklerin belirlenmesi amacıyla tasarlanan araştırmada betimsel analiz tekniği ışığında yapılan görüşmelerden elde edilen bulgular kategorileștirilerek incelenmiştir. Elde edilen bulgular katılımcı görüşleri eşliğinde sunulmuştur.

\section{Geçerlilik ve Güvenirlilik}

Sonuçların inandırıcılığı bilimsel araştırmaların en önemli unsurudur. Nitel araştırmalarda geçerlilik araştırmacının gözlemlerini ve veri toplama araçlarını gerçek ve doğru olarak ölçmesi, istenilen yapıyı doğru olarak belirtmesi$\operatorname{dir}$ (Balcı, 2013, s.207). Ölçümlerin hatalardan arındırılması olan güvenirlilik, iki ya da daha çok bağımsız gözlemcinin değerlendirmelerindeki uyuşma 
ile sağlanmaktadır (Balcı, 2013, s.207). Bu araştırmada verilerin denetime açıklığı, uzman görüşü, kayıt tekniği, katılımcı ifadeleri ve ayrıntılı betimleme geçerlilik ve güvenirliliğini oluşturan etmenlerdir.

\section{Bulgular}

Demiryolu işçilerinin çalışma yaşamlarında karşılaştıkları birtakım güçlükleri belirlemek amacıyla yapılan bu araştırmada katılımcılar ile yapılan görüşmelerden elde edilen veriler betimsel analize tabi tutulmuștur. Bu bağlamda elde edilen bulgular gruplandırılarak temalar halinde sunulmuştur. Araştırmada elde edilen bulgular; gelir ve yaşam koşulları, iş ve iş ortamları, iş sağlığı ve iş güvenliği temaları şeklinde üç alt başlık altında sunulmuştur. Ayrıca ilgili konular üzerine bazı katılımcı ifadelerine yer verilmiștir.

\section{Gelir Durumu ve Yaşam Koşullarına İlişskin Bulgular}

Katılımcı işçilerle yapılan görüşmede gelir ve yaşam koşullarına ilişkin sorular yöneltilmiştir. Elde edilen veriler ışığında; işçilerin aldıkları ücretlerin yetersiz olduğu, sadece zorunlu ihtiyaçlarını karşılayabildikleri ve sosyal (sinema, tatil, eğlence) harcamalarının kısıtlı olduğu bulguları elde edilmiştir. Katılımcı işçiler banka ve şahıs borçlarının bulunduğunu, elde ettikleri ücret ile öncelikle borçlarını ödediklerini, sonrasında kalan para ile gıda, kira, fatura ve aile masraflarını kısıtlı olarak karşılayabildiklerini ifade etmişlerdir.

"Aldığım ücret yeterli olmuyor. Hanım çalışmasa çok zor durumda olurduk, ikimiz çalıştığımız halde kıt kanaat geçinebiliyoruz."(Işsçi $i_{1}$; "Ailemin ihtiyaçlarını karşılamakta zorlanıyorum ve banka borcum bulunmakta. Borcum olmasa daha iyi geçim sağlarım. Üstelik sigara da kullanıyorum bu da olumsuz etkiliyor."(Ișşi 4 )

Katılımcı işçilerden üniversitede öğrenim gören çocuğu olanlar maddi anlamda daha fazla sıkıntı çektiklerini ifade etmektedir.

"Aldığımız ücret geçinmemiz için yeterli olmuyor. Paranın yarısı zaten borca gidiyor. Çocuğum üniversite de okuyor zar zor geçiniyoruz. Kalan kısım da yiyecek içecek ısınmaya gidiyor. Sosyal olarakyaptığım harcama yok en fazla zaman zaman futbol oynamak için halı sahaya gidiyoruz."(İşçi 3 ); “Çocuklar okuyor zaten pek gezemiyoruz, izin günlerimde ya da yıllık izin aldığım günlerde yakın bir yerlere günü birlik gidip piknik gezme yapıyoruz, onun dişında tatilmiş denizmiş pek bilmeyiz hem alışkınlık yok hem de kazandığımız yetmez oralara..." (İşçig)

Katılımcı işçiler son dönemlerde artan enflasyon neticesinde ücretlerinin iyice eridiğini, satın alma güçlerindeki azalma ile tüketimlerinin daha sınırlı hale geldiği ve tasarruf yapamadıklarını gelirlerinin tamamını harcamak zorunda kaldıklarını belirtmektedirler. 
"Aldığımız ücretin bir bölümü kiraya ve borca gidiyor, kalan para ile ancak mutfak masrafları ve ısınma, elektrik, su gibi masrafları karşıllyoruz. Şimdi son zamanlarda fiyatlarda arttı aldığımız meyve sebzenin miktarını azaltıyoruz bide başka yapacak bir şey yok." (İş̧í); ; “Cocukların giderleri, ev giderleri, okul falan derken aldığımız ücret gidiyor, her şeyin fiyatı artıyor bu da alım gücümüzü yok ediyor." (İşçi7) “Geleceğe yönelik bazı aylar altın falan alıyorduk ama şimdi fiyatlar artınca ne altın alabiliyoruz ne başka bir șey ancak yeme içme barınma ihtiyaçlarını

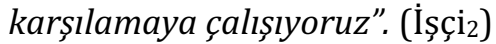

\section{İş ve İş Ortamlarına Yönelik Bulgular}

Araştırma kapsamında katılımcı işçilere iş ve iş ortamlarına yönelik sorular yöneltilmiştir. Katılımcı işçilerin tamamı çalışma ortamlarından ve iş arkadaşlarından memnun olduklarını ifade etmektedirler. İşlerinden memnun olduklarını ifade eden işçiler zaman zaman istenmeyen durumların yaşandığını fakat bunların kalıcı ve kronikleşmiş problemler olmadığını belirtmektedirler.

"İş yerimizde kronikleşmiş çalışma sıkıntılarımız yok, kimse kimseye kin tutmuyor. Evimizden çok neredeyse burada zaman geçiriyoruz. Bazen ister istemez küçük problemler yaşaniyor ama genel olarak huzurlu iş ortamımız." (İşçí) ; "İşimi severek yapıyorum ve 19 yıldır devam ediyorum. Sanat okulu motor mezunuyum kendi bilerek yaptığım işim olduğu için huzurlu bir șekilde yapıyorum."(İşçi 2 )

Lokomotif Bakım Atölyesi işin fiziki ağırlı̆̆ ve iş kazası açısından yüksek riskli bir departmanı olmasına rağmen katılımcı işçiler, bu şartların olumsuzluğundan bahsetmemektedirler. İşlerini kendi işleri gibi gördüklerini, hayatlarını bu işe adadıklarını, çocuk sayılabilecek bir yaşta TCDD bünyesinde çırak okulunda eğitim alıp, sonrasında çalışmaya başladıklarını ifade ederek iş ortamlarını içselleştirdikleri görülmektedir.

"14 yaşında başladım bu işe, 2 yıl çıraklık okulunda okuduk sonrasında direkt burada çalıșmaya başladım okul dâhil toplam 41 yıl oldu. Kendi dükkânım olsa bu kadar duramazdım. Buradaki makineler, kullandığımız alet-takım kendi malımız gibi benimseyerek çalışıyoruz." (İşçi $i_{3}$ ); "Benim yaşım 44 oldu ve 30 yıldır burada çalışıyorum. Şimdiye kadar keşke şu işte çalısssaydım demedim imkânım da oldu başka yerlerde çaıışmaya ama burayı bırakıp gidemem." (İşçis)

Katılımcı işçiler iş yerlerinde kullanılan makine ve teçhizatın ileri teknolojik ürünler olmadıklarını düşünmektedirler. Bazı durumlarda teçhizatların yetersiz olduğunu genelde manuel kullanım gerektiren malzeme ile çalıştıkla- 
rını belirtmiştirler. İşlerini kolaylaşması için kendilerinin geliştirdikleri birkaç yardımcı teçhizat olduğunu, böylelikle zaman ve bedensel güç tasarrufu yaptıklarını ifade etmişlerdir.

"İşimizde kullandığımız aletler el gücü ile kullanılmaktadır. Son sistem kullanılan malzememiz yok ama biz bazı işleri daha hızl yapabilmek için geliş̧tirdiğimiz makineler var. Bunlar sayesinde daha hızlı işimizi bitirebiliyoruz ve daha az yoruluyoruz."( İş̧̧i 1); "Bizim burada görüyorsunuz bilgisayarlı sistemler yok tüm iş iş̧̧inin elinde televizyonlarda gördüğümüz otomatik makineler yok ama yine de işimizi yetiştiriyoruz."( İşçi6)

Katılımcı işçiler iş yerlerinde yöneticilerin baskı, haksızlık ve mobbing gibi olumsuz tavırlarının olmadığını belirtmektedirler. Yöneticilerin işin niteliği ve işi yapma noktasında herhangi bir yaptırımlarının olmadığını dolayısıyla çalışma motivasyonlarını olumsuz etkileyen bir ortamın olmadığını ifade etmektedirler. İş ortamlarında çalışma barışının olduğunu ifade eden işçiler bu durumun işin verimliliğini olumlu etkilediğini düşünmektedirler. Hatta işlerini benimsediklerinden dolayı, iş yüklerini istemli arttırarak yedek parça kullanımını minimize etmeye çalıştıklarını, öncelikle onarım yapmaya ve kullanılmayan atıl parçaları değerlendirme yoluna gittiklerini ifade etmektedirler.

"İş yerimizde bana veya çalış̧an iş̧̧i arkadaşlara karşı art niyetli davranan hiçbir yönetici bulunmuyor. İşimi gayet rahat ve zorlama olmadan

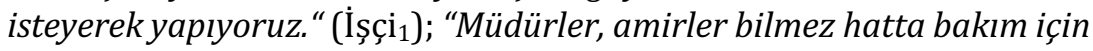
başka yerden gelen motorlar da bile parça değişimi yapıp işi kısa sürede tamamlamak yerine biz elimizde olan eski motorların üzerindeki parçalarını kullanıyoruz, o motorun üzerinden söktüğümüz arızalı parçayı daha sonra tamir etmeye uğraşıyoruz." (İşçi

Katılımcı işçiler iş ve iş ortamlarına yönelik teknik elemanın yetersizliği konusundan yakınmaktadırlar. İş yerlerindeki teknisyen ve mühendislerin yeterli bilgi ve donanımda olmadıklarını belirtmektedirler. İșe alımlarda uygun kişilerin alınması gerektiğini ifade ederek geçmişteki gibi TCDD'nin kendi eğitim okulu olması gerektiğini ve elemanını kendisinin yetiştirmesi gerektiğini belirtmektedirler. İş yerlerindeki personelin çoğunluğunun emekli olabilecek durumda olduğunu belirten katılımcılar, kalifiye işçinin emekliliği durumunda işlerin aksayacağını ve verimin düşeceğini düşünmektedirler. Ayrıca katılımcı işçiler iş eğitiminin yetersiz olduğunu, yeni alınan lokomotiflerin mekanik yapısını bilmediklerini dolayısıyla tamir ve bakım işinin olumsuz etkilendiğini ifade etmişleridir.

"Yeni alınmış bilmediğimiz bir makine geliyor belki devlet trilyonlar vermiştir. Hiç bilmediğimiz makineyi bırakıp alın bunu yapın diyorlar bize emanet ediyorlar. Öncesinde hiçbir eğitimimiz yok yapmaya çalışlyoruz kendimizce." (İşçi $\left.\mathrm{i}_{2}\right) ;$ "Burada çalışanların yaklaşık belki daha fazladır 
\%80'i emekliliği gelmiş kişiler. Alttan yetişen kalifiye eleman yok ilerde bu durum sıkıntı olacaktır. Bizim zamanında işi TCDD çıraklık okulunda öğrenip geldik, ama şimdi alınan işçiler, mühendisler, teknisyenler işi bilmiyorlar yani kalifiye eleman sı kıntımız var." (İşçi 3 ); "İdari personel, memurlar, müdürler sürekli o şehre bu şehre eğitime gidiyorlar. Biz işi yapıyoruz bizim eğitim almamız lazım ama hiç iş eğitimi almıyoruz. Yeni alınan lokomotifler geliyor hiçbir bilgimiz yok onu tamir etmeye uğraşıyoruz, bu durum hem zaman alıyor hem de işi düzgün ve hızh yapamıyoruz." (İşçi 4 ); "Açıkçası bazı onarımları nasıl yapacağımızı bilemediğimiz zamanlar oluyor, mühendisler bilmiyor çok eski ustalar bile bilmiyor. Bu onarımlar hakkında gelen makine hakkında önceden bilgilendirilsek daha iyi olur." (İşçi $1_{11}$ ) "Siz öğretim görevlisisiniz anlattığınız dersi öğrencinizden iyi bilmeniz gerekir ama bizde öyle değil başımızdaki mühendis, teknisyen işi bilmiyor her şeyi biz yapıyoruz". (İş̧̧i5)

\section{İş Sağlığı ve İş Güvenliği Üzerine Bulgular}

Katılımcı işçilere iş yerlerindeki iş sağlığı ve iş güvenliği üzerine sorular yöneltilmiștir. Alınan cevaplar genel olarak değerlendirildiğinde iş yerlerinde, iş sağlığı ve iş güvenliği üzerine alınan önlemlerin yetersiz olduğu, zaman zaman iş kazalarının yaşandığı, sağlıklarını olumsuz etkileyen durumların olduğu tespit edilmiştir. Katılımcı işçiler, işverenin iş sağlığı ve iş güvenliği üzerine aldığı önlemlerin geçmiş dönemlere nazaran daha iyi olduğunu belirtmelerine rağmen işçilerin görüşleri alınmadan yapılan uygulamaların etkisinin olmadığını ifade etmektedirler. Ayrıca iş sağlı̆̆ı ve iş güvenliği önlemleri için verilen kıyafetlerin kalitesiz ve işin yapısına uygun olmadığını, kullanılan teçhizatların kısa sürede kıyafetleri yıpratarak kullanılamaz hale geldiğini belirtmektedirler. Katılımcı işçilerin iş sağlığı ve iş güvenliği üzerine bazı ifadeleri şu şekildedir:

"İş yerimizde aydınlatma yetersiz özellikle kanalların aydınlatması iyi

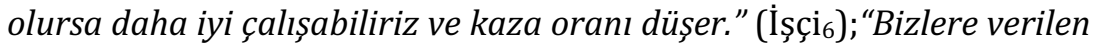
koruyucu malzemeler sentetik klyafetler. Sprel ve kaynak makinesi ile çalışınca yırtılıyor, yanıyor. Bu malzemeler işimize uygun değil. Yılda bir defa veriliyor bu malzemeler yırtılınca dışardan getirdiğimiz malzemeler ile idare ediyoruz." (İş̧̧i 4 ); "Bizim iş ortamımızda iş güvenliği sıfır tamamen slfir. Aydınlatma, kanalların temizliği yağlı olması, sehpaların düzensizliği, yüksek oranda ses ve egzoz gazı çok olumsuz etkiliyor." (İşçi 2 ); "İşs sehpaları yapıldı ama bizden görüş alınmadan yapıldığı için eskisinden kötü sehpa oldu yine çözüm olmadı çok slk sehpa ve makine arasına düşme kazaları yaşanıyor."(İş̧̧i5); "Verilen korucu malzemeler çok dayanıksız bizi yeterince korumuyor onu geçtim hemen parçalanıp gidiyor, yapacak bir şey yok kendimiz bir şeyler ayarllyoruz." (İş̧į) 
Katılımcı işçiler iş ortamlarındaki yüksek derecede ses ve egzoz dumanından olumsuz etkilendiklerini belirtmektedirler. Yapılan havalandırma sisteminin iş yerine uyumsuz olması ve bu sistemi kullanmayı bilen personelin olmamasından dolayı eski hava bacalarının kullanıldığını ifade etmektedirler. Ayrıca iş yerindeki yüksek ses işçilerin duyma bozuklukları yaşamalarına sebep olmaktadır. Katılımcı işçiler bu durumu şu şekilde ifade etmektedirler:

"Egzoz dumanı bizi olumsuz etkiliyor havalandırma sistemi çok yetersiz beni ve diğer arkadaşları çok olumsuz etkiliyor. Şu da var ki ısınmamız gayet iyi eskiden -20 derecede çalıştığımız oluyordu ama şu an ısınma problemimiz yok" (İşçi 3 ); "Dumandan korunmak için maske kullanılmıyor aldığımız maskeler egzoz dumanına etkili olmuyor. Ses desibeli çok fazla olduğu için hepimizin kulaklarımızda problem var." (İşçi ${ }_{1}$ ); Aslında kulaklık kullanmamız gerekiyor, verildi de ama onu kullanınca kendi aramızda zor anlaşıyoruz o yüzden duyma sorunları hemen hemen her-

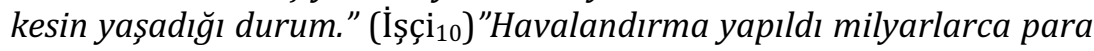
verildi yapıldı ama kullanmayı bilen yok çalışmıyor atıl bir şekilde duruyor."( İşçi

\section{Sonuç}

Türkiye'nin önemli bir taşımacılık kolunu oluşturan TCDD'de görev yapan işçilerin yaşadıkları güçlüklerin belirlenmesi amacıyla gerçekleştirilen bu araştırmadan elde edilen bulgulara göre; katılımcı işçiler çalışma ücretlerinin yetersiz olduğunu ifade etmektedir. Elde ettikleri gelirin bir kısmı ile banka ve şahıslara olan borçlarını ödeyen işçiler kalan para ile ancak zorunlu ihtiyaçlarını karşılayabildiklerini ve işçiler kazançlarının yetersizliği sebebiyle sosyal harcamalar (sinema, tiyatro, tatil, gezi, vb. gibi) yapamadıklarını belirtmektedir. Ayrıca kazançlarının yetersizliği işçilerin tasarruf yapmalarına da imkân vermemektedir. Özellikle çocuk sahibi olan ve çocukları eğitim gören işçiler ile eşi çalışmayan işçiler maddi olarak daha fazla güçlük çektiklerini ifade etmektedir.

Demiryolu işçileri genel olarak çalışma ortamlarından ve iş arkadaşlarından memnun olduklarını ifade etmektedirler. Katılımcı ifadelerine göre; bazı durumlarda küçük problemler yaşansa da iş yerinde kronikleşmiş ve devam eden sorunların olmadığı görülmektedir. İşçiler yaptıkları işin fiziksel olarak zor ve yorucu olmasından dolayı çalışma motivasyonlarının düşmediğini ve işlerinden memnun olduklarını ifade etmektedirler. İşçilerin atölyede kullandıkları makine ve teçhizatların ileri teknoloji ürünü olmadığı, genellikle bedensel güç gerektiren makine ve teçhizat ile çalıştıkları görülmektedir. Bazı işlerin hızlı ve verimli yapılabilmesi, zaman ve bedensel güç tasarrufu için işçiler kendi teçhizatlarını geliştirdiklerini belirtmişlerdir. Kurum kültürü ile tecrübe kazanan ve çıraklık eğitimi alan, çocuk yaşta TCDD bünyesine katılan işçiler, iş yerlerini içselleştirmiş ve benimsemiş durumdadırlar. İşçiler, iş yerinde yöneticiler tarafından baskı, mobbing ve haksız davranışın olmadığını 
belirterek çalışma barışının hâkim olduğunu ifade etmektedirler. Katılımcı ifadelerine dayanarak çalışma barışının ayrıca motivasyonlarını arttırdığı ve işçilerin iş yerlerini daha fazla benimsemelerine sebep olduğu görülmektedir. Demiryolu işçileri iş yerlerinde teknik elemanın yetersizliği ve mevcut elemanların bilgisizliği konusunda yakınmaktadırlar. İşçiler; iş yerlerindeki teknisyen ve mühendislerin demiryolu işinin niteliği ile ilgili yeterli bilgi ve donanıma sahip olmadıklarından dolayı bakım ve onarımın tespitinden neticesine kadar tüm işlemleri kendilerinin yürüttüklerini belirtmektedirler. Katılımclar; personel istihdamında daha dikkatli olunması gerektiği ve istihdam edilecek personelde liyakate uygun davranılması gerektiği yönünde görüş bildirmişlerdir. Ek olarak TCDD'nin daha önceden uyguladığı gibi kendi bünyesinde bulunan ve teorik bilgi ile mesleki uygulamayı birleştiren çıraklık okullarında kurumun personelinin yetiştirilmesi gerekliliğini ifade etmektedirler. Ayrıca işçiler çeşitli konularda eğitime ihtiyaç duyduklarını ancak yeterli düzeyde iş başında eğitim ve hizmetiçi eğitim olanaklarından faydalanamadıklarını belirtmişlerdir. Özellikle yeni alınan lokomotiflerin mekanik yapısını bilmemeleri nedeniyle tamir ve bakım işinin verimli ve hızlı olmadığını ifade etmişlerdir.

Demiryolu işçileri, iş yerlerinde, iş sağllğı ve iş güvenliği üzerine alınan önlemlerin yetersiz olduğunu, zaman zaman iş kazalarının yaşandığını, sağlıklarını olumsuz etkileyen durumların olduğunu ifade etmektedirler. Katılımcılara göre geçmişe oranla iş sağlığı ve güvenliği bağlamında iyileştirmeler olmasına rağmen konu ile ilgili alınan önlemler işçilerin görüş ve önerilerine başvurulmadığı için yetersiz kalmaktadır. Ayrıca iş sağlığı ve iş güvenliği önlemleri için verilen kıyafetlerin kalitesiz ve işin yapısına uygun olmadığı, kullanılan teçhizatların kısa sürede kıyafetleri yıprattığı ve kullanılamaz hale getirdiği görülmektedir. İşçiler iş ortamlarında yüksek derecede ses ve egzoz dumanın sağlıklarını olumsuz etkilendiklerini, yapılan havalandırma sisteminin iş yerine uyumsuz olması ve bu sistemi kullanmayı bilen personelin olmamasından dolayı sorun yaşamaktadırlar. İş yerindeki yüksek ses işçilerin büyük bir oranında duyma bozuklukları yaşamasına sebep olmaktadır.

\section{Öneriler}

Araştırma kapsamında elde edilen bulgular doğrultusunda demiryolları çalışanlarının çalışma yaşamlarında karşılaştıkları güçlüklerin hafifletilmesi adına aşağıda yer alan hususlar önerilmektedir:

- Döviz kuru dalgalanmaları ve enflasyon karşısında erimekte olan işçi ücretlerinde iyileştirmelerin yapılması,

- TCDD bünyesinde bakım ve onarım işlemlerinde kullanılan alet ve teçhizatlarda revizyon yapılması ve yeni teknolojik ürünlerin kullanılmasl, 
- Personel eksikliğini gidermek için personel istihdamının arttırılması, özellikle teknisyen ve mühendislerin iş hakkında yeterli bilgi ve donanımda olduklarının test edilmesi,

- Mevcut personele TCDD envanterine katılan yeni makineler hakkında verilen eğitimlerin yoğunlaştırılması ve sürekliliğinin sağlanmasl,

- TCDD’nin kendi personelini yetiştirdiği ve 1998 yılında kapatılan eğitim kurumlarının tekrar aktif hale getirilmesi ve personel istihdamında bu kurumlardan faydalanılması,

- 28. Dönem Toplu İş Sözleşmesi'nde belirtilen işçilere verilecek giyecek ve koruyucu malzemelerin kısa sürede yıpranması ve iş sağlığı ve güvenliği konusunda yetersiz kalması sebebiyle daha kaliteli malzeme alımı yapılması,

- İş ortamlarında iş sağlığı ve güvenliği önemleri alınırken işçilerin görüşlerine başvurularak ortak karar mekanizması kullanılması önerilmektedir.

\section{Kaynaklar}

Akalan, A. O. (2010). Bir kurum olarak Türkiye Cumhuriyeti Devler Demir yollarl tarihi. (Yayımlanmamıș Doktora Tezi). Hacettepe Üniversitesi/ Atatürk İlke ve İnkılapları Enstitüsü, Ankara.

Akbulut, G. (2012). Osmanlı Devleti'nden Türkiye Cumhuriyeti'ne gerçekleşmeyen demiryolu projeleri ve etkileri (1876-1939). Atatürk Dergisi. 1(1). 225-255.

Altınok, S. (2004). Türkiye'de ulaştırma politikaları, karayolları ve demiryollarının mukayesesi. Sosyal Ekonomik Araştırmalar Dergisi, 1(1-2), 72-87.

Altundaş, E., Arslan, G., Akıngöl, Z., Varol, A., Turan, C., ve Kalaça, S. (2010). Demiryolu işçilerinin çalışma koşullarından kaynaklanan sağlık sorunları. Mesleki Sağlık ve Güvenlik Dergisi, 10 (37), 36-43.

Balcı, A. (2013). Sosyal bilimlerde araştırma: Yöntem, teknik ve ilkeler. Pegem A Yayıncllik.

Budakoğlu, I. İ., Bakar, C., Atlı, K., ve Akgün, S. (2015). T.C. devlet demir yolları behiç bey fabrikalarında çalışan işçilerde iş kazaları sıklığı ve bazı risk faktörleri. Mesleki Sağlık ve Güvenlik Dergisi, 8(29), 27-32.

Büyüköztürk, Ş., Çakmak, E. K., Akgün, Ö. E., Karadeniz, Ș., ve Demirel, F. (2014). Bilimsel araștırma yöntemleri. Ankara: Pegem Akademi.

Collins, K. M. T., Onwuegbuzie, A. J. ve Jiao, Q. G. (2006). Prevalence of mixedmethods sampling designs in social science research. Evaluation \& Research in Education, 19 (2), 83-101.

Demiryol-İș (1996). 21. Yüzyıla doğru demiryollarının modernizasyonu yeni bir gelişme stratejisi, Ankara: Moray Ajans

Glesne, C. (2012). Nitel araştırmaya giriş, (A. Ersoy \& P. Yalçınoğlu, Çev. Ed.). Ankara: Anı.

Kahya, E. (1988). Türkiye'de ilk demiryolları. Belleten, 202, 209-18 
Kent ve Demiryolu (2014). Demiryolu meslek okulu yeniden açılır mı? 15.05.2021 Tarihinde http://kentvedemiryolu.com/demiryolu-meslekokulu-yeniden-acilir-mi/ adresinden erişilmiştir.

Koçak, D. (2014). Demiryolu çalışmalarında işs sağlı̆̆ı ve güvenliği vagon bakım onarım atölyesi risk değerlendirmesi örneği. Çalışma ve Sosyal Güvenlik Bakanlığı. Çalışma ve Sosyal Güvenlik Eğitim Uzmanlığı Tezi. Ankara.

Nastasi, B. (2015). Study notes: Qualitative research: Sampling ve sample size considerations. http://webcache.googleusercontent.com/search?q=cache:qN67UD2NsgJ:https://my.laureate.net/Faculty/docs/Faculty\%2520Documents/qualit res smpl size consid.doc+vecd=1vehl=envect=clnkvegl=tr. Erişim tarihi: 05.11.2020

Patton, M. Q. (2014). Nitel Araştırma ve Değerlendirme Yöntemleri. (Çeviri Editörleri: Mesut Bütün ve Selçuk Beșir Demir), Ankara: Pegem Akademi

Sönmez, V. ve Alacapınar, F. G. (2011). Örneklendirilmiş bilimsel araştırma yöntemleri. Ankara: Anı Yayıncilı.

Şenol, S. B. (1994). Tülomsaş; Türkiye demiryollarında 100 yıl, Eskişehir.

TCDD İstatistik Ylllığl 2000-2004. 17.05.2021 Tarihinde https://static.tcdd.gov.tr/webfiles/userfiles/files/ 20002004ist.pdf adresinden erişilmiştir.

TCDD İstatistik Ylllığı 2002-2006. 17.05.2021 Tarihinde https://static.tcdd.gov.tr/ webfiles/userfiles/files/2006yillik.pdf adresinden erişilmiştir.

TCDD İstatistik Ylllığı 2006-2010. 17.05.2021 Tarihinde https://static.tcdd.gov.tr/ webfiles/userfiles/files /20062010yillik.pdf adresinden erişilmiştir.

TCDD İstatistik Yıllığı 2010-2014. 17.05.2021 Tarihinde https://static.tcdd.gov.tr/ webfiles/userfiles/files /20102014yillik.pdf adresinden erișilmiștir.

TCDD İstatistik Ylllığı 2013-2017. 17.05.2021 Tarihinde https://static.tcdd.gov.tr/ webfiles/userfiles/files/20132017yillik.pdf adresinden erişilmiştir.

TCDD İstatistik Ylllı̆ı 2015-2019. 17.05.2021 Tarihinde https://static.tcdd.gov.tr/webfiles/userfiles/files/istrapor/20152019\%20\%C4\%BOSTAT\%C4\%B0ST\%C4\%B0K\%20YILLI\%C4\%9EI\%20.pdf adresinden erișilmiştir.

TCDD İstatistik Ylllı̆ı $2016-2020.07 .12 .2021$ Tarihinde https://static.tcdd.gov.tr/webfiles/userfiles/files/istrapor/20162020ist.pdf adresinden erişilmiştir.

Topgül, S. (2017). TÜLOMSAŞ kuruluşu ve kurulduğu dönemdeki çalışma ilişkilerinin sözlü tarihten yararlanma yolu ile incelenmesi. Gümüşhane Üniversitesi Sosyal Bilimler Enstitüsü Elektronik Dergisi, 8(21), 184-196.

Yıldırım, A. ve Şimșek, H. (2013). Sosyal bilimlerde nitel araștırma yöntemleri. Ankara: Seçkin Yayıncılık. 